\section{E-Government Implementation, Work Process Changes \\ and Competency Training in Spanish Town Councils}

\author{
Enrique Claver-Cortés \\ Business Organization Department, \\ University of Alicante, Spain \\ Enrique.Claver@ua.es \\ Susana de Juana-Espinosa \\ Business Organization Department, \\ University of Alicante, Spain \\ Susana.Espinosa@ua.es \\ Jorge Valdes-Conca \\ Business Organization Department, \\ University of Alicante, Spain \\ Jorge.Valdes@ua.es
}

E-Government Implementation, Work Process Changes and Competency Training in Spanish Town Councils

\begin{abstract}
This paper aims to empirically explore whether changes in technological infrastructures and working processes have been perceived by local public employees, and if training programs have been used as a way to introduce these changes in a strategic manner. The analysis of the differences in the situation between 2005 and 2014 reveals an increased investment in technology and a decreased investment in training, and that public employees have not perceived a significant improvement in the way they work and in their efficiency levels. These findings emphasize the importance of competence-based management for the effective provision of public services.

Purpose - This paper has as its aim to empirically explore whether changes in technological infrastructures and working processes have been perceived by local public employees, and if training programs have been used as a way to introduce these changes in a strategic manner.

Design/Methodology/Approach - A longitudinal analysis was carried for this purpose asking about the presence of training actions addressed to the employees of Spanish public administrations and about the perception that ICT area managers have in regards to the effects caused by the introduction of e-government strategies.

Findings - The results obtained show that town councils have increased their investment in technical aspects of e-government, but not in the development of competences to use the technology. In addition, the fact that public employees have not perceived a significant improvement in the
\end{abstract}

\section{Psynergía}

International Journal of Synergy and Research Vol. 5, 2016 pp. 5-18 
IJSR 5 way they work and in their efficiency levels leads to the conclusion that a decreased investment in competency training is not conducive to a greater sense of efficiency in the provision of public services.

Research limitations/implications - The limitations of this paper lie on the lack of consideration of certain parameters which might influence strategic e-government implementation; plus incurring in single-bias response and considering only one case (Spain) in the research. The statistical analysis is merely descriptive, although it provides the researchers with clear results.

Practical implications - Public managers and policy makers should reflect on the long-term effects of their e-government decisions or - alternatively - the absence of such effects. Shortterm 'patches' are only useful to meet a specific need during a certain period, whereas change management requires a more far-reaching, long-term look which can overcome the budgetary limits and the traditional bureaucratic barriers.

Originality/Value - This paper presents the results of a longitudinal analysis carried out over nine years that explores first-hand opinions of e-government professionals, linking competency-base management and e-government success.

Keywords - public administration, ICTs, training, competency-based management, e-government, human resources, longitudinal analysis, Spain.

\section{Introduction}

The transition to an interactive management with the customer through Information and Communication Technologies (ICTs) has been long tackled by the private sector, aware of the need to approach its customers through both widespread and useful tools for the delivery of a better service and a stronger orientation towards those customers. However, this transition is stalled in public sector organizations (PSOs), because of their traditional mechanical structures. In this respect, one of the main instruments which facilitate and guide this transit is public employee training, with a two-fold aim: firstly, endowing those public employees with the knowledge and skills needed for the utilization of the ICT tools inherent to e-government; and secondly, instilling the behaviors and attitudes which characterize the acceptance and internalization of a greater orientation to the 'customer' by means of more flexible working methods, with a higher degree of autonomy and under the parameters of a more organic type of organizational structure, such as the orientation towards customers and the satisfaction of their needs through the technology focused on citizens, but also the orientation aimed at results and necessities, receptivity and connectivity, opening and proactivity within the framework of some new procedures, ways to establish relationships, etc. (Guijarro et al., 2015).

The aim of this paper is to study the variety of actions undertaken by the different Spanish town councils as far as training is concerned, both in the ICT knowledge and skills typically associated with e-government and in behaviors and attitudes which are in tune with the strategic rethinking entailed by this change, as well as the perception of a true change that the public employees of those town councils have had. A questionnaire was sent for this purpose, both online and by postal mail, to the IT managers of Spanish local administrations in 2005 and 2014. The choice of this analysis period will allow us to weigh up the differences perceived before the economic-financial crisis and once we were immersed into it. The present work consequently makes a two-fold contribution: 
on the one hand, examining the actions undertaken in the field of training for the purpose of dealing with this change, both in terms of infrastructures and regarding the strategic orientation required for the adoption of e-government; and on the other hand, to calibrate the evolution and perception of the results obtained with such initiatives over a time period which starts with the economic crisis and finishes at the present moment, while we are still immersed into it.

The structure of the paper is as follows. A brief summary of the most important contributions to the literature about the connection between ICTs and the training actions undertaken by public institutions - as well as the relationship that public employees maintain with the specific administration for which they work - is followed by an explanation of the methodology used in the present study, after which there will be made a simple and direct description of the results as well as the evolution in time of the perceptions about the relationships between employees and administrations, together with the presence of certain training and technological instruments that favor the transition to a strategic and not merely infrastructural e-government in Spanish town councils. The paper finishes with a number of conclusions drawn from the research work which can make this transition process easier for other public entities, additionally encouraging local PSOs as a whole to carry out a self-reflection exercise with regard to the effectiveness level achieved through the measures introduced, based on the opinions expressed by the employees who have directly experienced the effects of those measures.

\section{The role of ICTs and employee training in the transition to a strategic e-government model}

Even though bureaucracy was originally defined as a "formal institution with a clear and evident division of work, abstract rules, impartial procedures and decision-making, which utilizes technical qualifications and professionalism as the basis of promotion for employees" (Weber, 1979), this concept is currently assimilated to that of public administration, which still follows these highly formalized hierarchy and centralized decision-making parameters, to the detriment of greater flexibility but with the aim of being as efficient, socially equitable and transparent as possible, since it is financed with the public treasury. Furthermore, according to Spicer (2015), public administration is strongly politicized, which makes it clear that an efficient decision-making process therein can only be achieved through its adaptation to the different political sensitivities and the search for consensus between often conflicting interests.

Therefore, we are faced with strongly hierarchical structures, with highly mechanical bureaucratic processes, where the need for change when it comes to adopting the e-government model requires an organizational change from the bottom of the structure up to its strategic apex. Such an organizational change must necessarily include a modification of public employees' working procedures and tools, in such a way that they not only acquire the knowledge needed to use ICTs as a form of communication and management in public services but also adopt a greater orientation towards customers through parameters related to the quality and supply of these services for citizens. Nevertheless, the resistance to change on the part of public organizations becomes visible with justifications typical of institutions such as political independence
E-Government Implementation, Work Process Changes and Competency Training in Spanish Town Councils 
IJSR 5

or stability in the delivery of public service to citizens. Before this scenario, the dynamic management of resources and capabilities, along with the assignment inefficiencies and the consequent opportunity costs highlighted by Grant (1996), becomes a highly complicated task, the need existing for a modification in the organizational vision of the administration at every level (Burn and Robins, 2003).

Precisely, these constant demands derived from inefficiency have driven the intention of change within PSOs, aware of the need to adapt the delivery of their public services not only to the technological changes associated with ICTs but also to the way in which services are delivered, the communication with citizens and other institutions, the active involvement of citizens through the Internet and social networks, etc. It all entails a change in the orientation to the 'customer'. Such a change, with a higher degree of service personalization/customization, as well as an emphasis on service quality, makes it necessary for public employees to have more flexibility, autonomy, knowledge and values which can give a more organic nature to their functions, moving away from the mechanistic methodology which traditionally characterizes these structures (Šiugždinienè, 2006). Consequently, the more mechanistic the organizational structure of the entity, the greater training effort (in both knowledge and competences) will need to be made by the organization in question with regard to its employees. This is how the New Public Management (NPM) theory (Hood, 1991, 1995; Dunleavy and Hood, 1994) arises as a result of the analysis that the public sector has been performing in relation to the management models adopted by private companies with the incorporation of ICTs (Ferlie et al., 1996), oriented towards greater flexibility and organic rather than mechanical structures, in short, permitting a more agile performance of the functions corresponding to these public institutions. This approach towards efficiency and a decreased bureaucracy has been tagged as insufficient and obsolete by some authors (Dunleavy et al., 2006), but it is a valid paradigm when studying changes in government and bureaucracy instead of "serious long-term societal problems and the day-to-day problems of citizens" (de Vries, 2010, p.5).

Amongst the areas transferred from the private to the public enterprise stands out the implementation of Information and Communication Technologies (ICTs), since the latter make it possible to increase the efficiency of public organizations, insofar as they reduce costs and time (del Águila Obra, 2000; Johnson and Mullen, 2000; Ho, 2002). Thus, tools such as websites or databases permit to offer and channel information and documentation of interest for the development of internal governmental activity and the delivery of public services (Prokopiadou et al., 2004).

Nevertheless, apart from the adoption of these ICTs as citizen-focused communication and management tools, a strategic type of transition towards e-government must also necessarily envisage a reconceptualization of the traditional working methods. Such a reconceptualization implies accepting that citizens no longer play the role of passive agents in the relationships maintained with their respective public administrations. The new digital platforms offer those citizens continuous and dynamic connectivity with the administration, not only when it comes to searching for information, requesting it, carrying out formalities, etc. but also to exchanging opinions and influencing the work dynamics of the public institution through social networks, web pages, blogs, etc. For all these reasons, the change process does not only consist in the automation of tasks 
and the development of training actions so that public employees can familiarize with such technologies but also in a change of strategic orientation focused on flexibility and quality, adopting structures of a more organic nature, and moving away from the watertight and stable procedures of the typical mechanistic processes inherent to these organizations (Op De Beeck and Hondeghem, 2010). In short, the purpose of change implies a strategic modification of employees' competences, so that the new public management model can mean a stable, lasting transformation and not only a mere lightening of the administrative formalities typical of town councils (Ho, 2002; Torres, Pina and Acerete, 2005). In this respect, McIvor et al. (2002) suggest, as an essential principle in the transition towards information society, that encouragement is given to competences such as innovation and creativity, and also that adequate training is provided for the use of these ICT tools, given the added value that they can provide in terms of efficiency (Margetts, 2009). Along this same line of reasoning can be found works such as that of Norris and Reddick (2012), which detected increases in the adoption of strategic actions related to e-government in US town councils between 2004 and 2011. Nevertheless, these actions have sometimes not gone beyond the implementation of ICTs for public service delivery purposes, without actually undertaking a reconceptualization of the management model and providing it with the stability and solidity required for a true generation of added value.

Considering all the above, the training of employees, not only in the use of ICTs (Galindo Meño, 2004) but also in the development of behavioral competences which can stabilize and exploit the model to the full, appears as a crucial factor (Mahler and Regan, 2003). It is necessary to break with the inertia that the bureaucratic management of these institutions has generated for so many years, creating ways of behaving, thinking, and acting that need to be reshaped within a new electronic context (de Luna Noyola, 2008).

\section{Methodology}

Based on the theoretical framework presented in the previous section, the next section focuses on the analysis of the extent to which the different public administrations, more specifically the local administrations (town councils) situated in the Spanish territory, have undertaken this strategic transition towards e-government by means of the actions described above. That is to say, on the one hand, a renovation of infrastructures with the implementation of ICTs which can facilitate and develop interaction with citizens, and on the other hand, training actions addressed to public employees focused both on the knowledge about the utilization of these new infrastructures and on the competences which can make possible a service which, in addition to being highly personalized and flexible, is also more strongly oriented to the customer. Finally, an analysis will be carried out in order to determine whether public employees actually perceive the changes caused by the previous actions or not, and whether they feel that they are currently in a better position for the strategic transition to the e-government model with less mechanic and more organic actions that add greater value to the performance of their functions. In this sense, three working propositions are put forward:

- Proposition 1: Town councils increased their investment in ICTs between 2005 and 2014.
E-Government Implementation, Work Process Changes and Competency Training in Spanish Town Councils 
IJSR 5

- Proposition 2: The human resources of Spanish town councils received more training courses between 2005 and 2014.

- Proposition 2a: The human resources of Spanish town councils received more training courses focused on the development of technological skills.

- Proposition 2b: The human resources of Spanish town councils received more training courses focused on the development of intangible skills in line with more organic working procedures.

- Proposition 3: The employees of public administrations perceived changes in their way of working towards a less bureaucratic model between 2005 and 2014.

Seeking to find an answer to all these questions, an electronic questionnaire was sent to the municipalities which had more than 5,000 inhabitants in 2005. Even though the use of different information sources in each town council would not only have proved interesting but also eliminated the single-respondent bias, it was the researchers' decision to focus only on the figure of the IT manager in order to achieve a higher response ratio and a more homogeneous as well as technical vision about the implementation of technology in town councils. That same questionnaire was resent in 2014 to the 1,000 largest-sized municipalities which fulfilled the requirements demanded from those interviewed in 2005. Therefore, amongst these 1,000 town councils were the 960 which had originally formed part of the study population in 2005. This variation in the size of the population between both dates had to do with the alterations suffered by municipalities in their population censuses during this nine-year period. These IT managers had access to the questionnaire online by means of a link provided by electronic mail in 2005 and through a combination of a letter and an e-mail message in 2014.

Three blocks of questions were devised in order to find a response to the aforementioned propositions. Since the research's aim consisted in examining the evolution operated in the presence of actions undertaken to manage change, two lists of dichotomous items were included in the first and second block: one which reflects the existence of intranets, databases, news pages and other technological measures (Proposition 1); and another one which brings together the training actions carried out as a preparation to implement the principles of e-administration (Proposition 2). Finally, a list of eight items on a 1 (I totally disagree) to 5 (I totally agree) scale measures a set of statements which reflect the interviewees' opinion about the reality of those effects in the context of their town council, obtained after reviewing the literature. These elements will be used for giving a response to Proposition 3.

165 answers were obtained from 960 town councils interviewed in 2005, and 231 out of 1,000 in 2014 , which implies response rates of $17.2 \%$ and $23.1 \%$, respectively (sampling error: 7.78 and 5.66). The initial sample of town councils interviewed in 2005 comprised all the Spanish autonomous regions but one: Navarre. A representation of them all was obtained during the second wave in 2014, though. Likewise, a means difference test has shown that the sample distribution by municipal population was representative of the total population both in 2005 and in 2014. Since the study has an essentially exploratory nature, the data analysis techniques utilized are descriptive; instead, the longitudinal analysis was carried out with tests referred to significant means variances and percent variations. 


\section{Results and discussion \\ 4.1. Proposition 1: Town councils increased their investment in ICTs between 2005 and 2014}

Table 1 shows us the presence in percentage terms as well as their relative variation regarding the implementation of ICTs associated with e-government. It can indeed be observed that the proportion of town councils implementing these technologies grew during this time period, as could be expected (Norris and Reddick, 2012).

It is firstly worth stressing the high increase percentages identified in tools for teamwork which, despite continuing to be the least common type of ICT amongst town councils, is implemented in practically one out of four. This piece of information deserves a special mention because the ability to share information in work teams arises as an essential element when it comes to avoiding the inefficiencies derived from an excess of bureaucratic values in public administration (McIvor et al., 2002).

Instead, the most common ICT is the database for HR management - in 2005 as well as in 2014. This tool serves both to monitor the information about public employees and to make decisions regarding the G2E relationship, such as identifying the training needs or measuring employees' efficiency in accordance with the postulates of Åkesson et al. (2008) and Prokopiadou et al. (2004).

\begin{tabular}{lcccc}
\hline ICTs & 2005 & 2014 & Variation & Percent variation \\
\hline Intranet & $53.9 \%$ & $71.7 \%$ & 17.8 & $33 \%$ \\
\hline HR database & $67.3 \%$ & $80.2 \%$ & 12.9 & $19.2 \%$ \\
\hline Teamwork tools & $13.9 \%$ & $22.6 \%$ & 8.7 & $62.6 \%$ \\
\hline Employee's suggestion box & $15.2 \%$ & $16.5 \%$ & 1.3 & $8.6 \%$ \\
\hline
\end{tabular}

Source: Authors' own study

The presence of intranets in town councils also experienced a remarkable growth $33 \%$ - which shows that the local PSOs have fully understood the advantages that this tool can bring it ( $\AA$ kesson et al., 2008). As for the public employee's suggestions box, despite still remaining a residual tool in their technological heritage, it is currently going through an expansion process, as proved by the fact that one in six town councils has incorporated it.

All the above enables us to accept the first proposition and to state that town councils really increased their investment in ICTs during the period examined.
E-Government Implementation, Work Process Changes and Competency Training in Spanish Town Councils

Table 1. ICT tools in town councils. Variation between 2005 and 2014 
IJSR 5

Table 2.

Training addressed to local public employees. Variation between 2005 and 2014

\subsection{Proposition 2: The human resources of Spanish town councils received more training courses between 2005 and 2014}

Seeking to carry out an in-depth analysis about the measures used by town councils for training, both in ICT use and in the development of competences, that has as its aim to achieve a strategic implementation of e-government, Table 2 reveals how often the courses organized by town councils took place during the period under study. The first outstanding aspect can be found in the slightly lower average course frequency, from 5.3 to 5.07 courses per town council: while $11.5 \%$ of entities had not offered any training courses to their employees in 2005 , this figure grew to $15.6 \%$ by 2014 . It is thus impossible for us to categorically assert that Proposition 2 must be completely accepted or rejected. Propositions 2.1 and 2.2 will now be examined for a detailed analysis according to the type of training imparted.

\begin{tabular}{|c|c|c|c|c|c|}
\hline \multicolumn{2}{|c|}{ Course content } & 2005 & 2014 & Variation & Percent variation \\
\hline \multirow{6}{*}{ 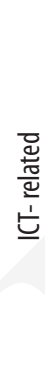 } & Public management software & $83.8 \%$ & $77.1 \%$ & -6.7 & $-8.00 \%$ \\
\hline & Office automation & $87.6 \%$ & $73 . \%$ & -14.4 & $-16.44 \%$ \\
\hline & e-Mail & $76 \%$ & $69.7 \%$ & -6.3 & $-8.29 \%$ \\
\hline & Internet & $74.8 \%$ & $63.6 \%$ & -11.2 & $-14.97 \%$ \\
\hline & Databases & $72.4 \%$ & $59.7 \%$ & -12.7 & $-17.54 \%$ \\
\hline & Website design & $35.8 \%$ & $28.6 \%$ & -7.2 & $-20.11 \%$ \\
\hline \multirow{4}{*}{ 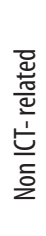 } & Team work & $38.4 \%$ & $36.8 \%$ & -1.6 & $-4.17 \%$ \\
\hline & Orientation to the customer & $40.1 \%$ & $37.7 \%$ & 2.4 & $-5.98 \%$ \\
\hline & Quality management & $37.3 \%$ & $30.7 \%$ & -6.6 & $-17.7 \%$ \\
\hline & Knowledge management & $30.6 \%$ & $30.3 \%$ & -0.3 & $-0.98 \%$ \\
\hline
\end{tabular}

Source: Authors' own study

- P2a: The human resources of Spanish town councils received more training courses focused on the development of technological skills.

The most popular courses are those dealing with office automation and software for public management, followed by those referring to Internet use, electronic mail, and databases. This highlights the priorities for town councils' human resources, since they tend to receive training on contents which can instantly be applied to their job. The negative variation between 2005 and 2014 reflects that public employees already had a number of consolidated computer skills and it was therefore deemed that the need to train them in those areas was less pressing. This is consequently regarded as an already 'passed' subject, which leads us to reject Proposition 2a. 
- P2b: The human resources of Spanish town councils received more training courses focused on the development of intangible skills in line with more organic work processes.

Less than half of town councils positively responded to the utilization of these training measures oriented to non-ICT-related subjects/contents such as teamwork, quality management or customer attention. These types of courses are directly linked to the NPM parameters and a strategic orientation towards more organic procedures, as can be seen in the literature and, however, their frequency cannot be compared to that of courses about ICTs. This difference may be due to the fact that such courses are less appealing to town council workers than those related to computers, which after all constitute their main tool of work and interaction with the outside world (with the exception of customer service face-to-face jobs, of course). This is clearly detrimental to the process of modernization in their town council, since the latter does not encourage such skills amongst its employees.

The negative offer variation between 2005 and 2014 in this particular group of training actions is minimal; hardly any variation exists on many occasions, though, above all in the cases of teamwork and knowledge management (McIvor et al., 2002). This fact suggests that certain town councils are still rethinking the status quo of the traditional bureaucratic culture (Schedler and Scharf, 2001) and recognizing the need to adapt and update the skills of their human resources for the introduction of new working methods and tools, thus, supporting the sense that it makes to adopt this change of strategic orientation. However, this recognition was still present in the same number of town councils, which means that, even though the significance of this orientation did not decrease during these years, this strategic type of training was not enhanced through the development of competences either.

\subsection{Proposition 3: The employees of public administrations perceived changes in their way of working towards a less} bureaucratic model between 2005 and 2014

Table 3 below allows us to reflect the data obtained with regard to the perception that the IT managers of the town councils interviewed expressed about the effects that ICT implementation had had on the organization of work and on internal users, both in 2005 and in 2014, which matches the findings of the works developed by Bueno García (2002), FEMP (2002), Holden, Norris, and Fletcher (2003).

It can firstly be observed that there are indeed significant changes in the average value obtained for some of the statements proposed in the questionnaire. The t-test confirms that significant differences exist at $5 \%$ between both waves of responses for half of the items (specifically, items 3, 4, 7, and 8, which refer to the improvements perceived by employees in e-administration matters, the reforms caused by NICTs in administrative procedures, as well as the normalization, standardization and integration of working processes). In other words, during the period comprised between 2005 and 2014, town council employees perceived that they had a deeper knowledge of the improvements that e-administration meant for them (Item 3); and were more conscious
E-Government Implementation, Work Process Changes and Competency Training in Spanish Town Councils 
IJSR 5

of the reform that e-administration had entailed in their administrative and working procedures (Item 4). More precisely, this reform seems to become apparent in the normalization and standardization of working methods (Item 7) and in the integration of internal working processes (Item 8), all of which confirms the postulates of McIvor et al. (2002). Furthermore, albeit not with a significant $10 \%$ difference, the t-test also shows us that town councils increased their perception about the necessity to have available the technology that they needed to carry out their task optimally (Item 1). No significant differences could be found between 2005 and 2014 for the remaining items $(2,5$, and 6 , referred to the demands of employees in the area of technological infrastructures, as well as the simplification and reduction of economic and time-related costs provided by such infrastructures).

It can also be seen that all the variations operated over this period were positive, except for Item 2. Expressed differently, the demand by public employees for an improvement in the municipality's infrastructures decreased in 2014 (albeit not to a significant extent). This negative variation may derive from the fact that town councils improved such infrastructures during that time interval (as proven in the first proposition), which is why workers no longer demanded them so often. In fact, this second item passed from being

\begin{tabular}{|c|c|c|c|c|}
\hline Effects on work processes & 2005 & $\begin{array}{c}2014 \\
\operatorname{Mean}(0)\end{array}$ & $\begin{array}{c}\text { Percent } \\
\text { variation }\end{array}$ & $\begin{array}{l}\text { Significant } \\
\text { Difference }\end{array}$ \\
\hline $\begin{array}{l}\text { Employees have at their disposal the technology } \\
\text { required to perform their work optimally }\end{array}$ & $3.4(0.89)$ & $3.68(1.1)$ & $5.44 \%$ & No \\
\hline $\begin{array}{l}\text { Demands of employees for the improvement of the } \\
\text { town council's ICT infrastructures have been detected }\end{array}$ & $3.51(1.16)$ & $3.39(1.26)$ & $-3.42 \%$ & No \\
\hline $\begin{array}{l}\text { Employees are aware of the improvements provided } \\
\text { by e-Administration }\end{array}$ & $2.68(1.04)$ & $3.08(1.07)$ & $14.92 \%$ & Yes** \\
\hline $\begin{array}{l}\text { ICTs have caused a reform of administrative and } \\
\text { working procedures }\end{array}$ & $3.39(1.05)$ & $3.9(1.14)$ & $15.04 \%$ & Yes** \\
\hline $\begin{array}{l}\text { ICTs have triggered a simplification of administrative } \\
\text { and working procedures }\end{array}$ & $3.36(0.99)$ & $3.57(1.21)$ & $6.25 \%$ & No \\
\hline $\begin{array}{l}\text { Cost and time reductions have been observed in the } \\
\text { processing of formalities }\end{array}$ & $3.34(1)$ & $3.51(1.2)$ & $5.09 \%$ & No \\
\hline $\begin{array}{l}\text { It has been possible to normalize and standardize } \\
\text { working models which did not use to have such } \\
\text { a status }\end{array}$ & $3.09(1.05)$ & $3.52(1.16)$ & $13.92 \%$ & Yes** \\
\hline $\begin{array}{l}\text { Internal working processes have been integrated } \\
\text { (unified) }\end{array}$ & $2.92(0.99)$ & $3.25(1.91)$ & $11.3 \%$ & Yes* \\
\hline
\end{tabular}

Table 3.

Effects on working processes. Variation between 2005 and 2014 
the one with the greatest weight within this survey block (in 2005) to having the third lowest value (in 2014).

In conclusion, it is possible for us to state that ICT introduction has indeed affected the way in which local public employees develop their professional activity, above all when it comes to standardizing their working methods and integrating internal working processes; however, this improvement does not result in a significant reduction of time and costs in the processing of formalities or in a simplification of administrative and working processes, which is actually in keeping with the findings of Sotiraku and Zeppou (2004). Proposition 3 can thus be partially supported.

In short, the present study offers us the image of a local administration concerned about the adaptation to the new economy which undertook training actions focused on ICT subjects from the very beginning of the transition period, even though a higher degree of passiveness appears with regard to the development of competences leading to a strategic and organic orientation of this change. The actions aimed at developing such a change of competences are still a minority, the same as they were ten years ago. Despite the fact that their number has been maintained or has experienced a slight decrease, their presence can anyhow be checked in just under half of the interviewed town councils.

As for the reforms of working processes in town councils, significant changes become visible between 2005 and 2014: public employees thought that they had the necessary tools to face this change process at their disposal, true changes in their work structures and procedures being perceived - precisely what was needed to achieve an efficient administration, especially as far as work standardization and process integration is concerned. Even though it is true that this change in the work structure has not been statistically backed by a significant increase in the simplification of processes and the reductions of economic and time-related costs in the processing of formalities, these assessments of public employees certainly improved in comparison to the ones that they had made in 2005, improvements which had already become evident in the entity's work structures.

\section{Discussion, conclusions, reflections and limitations}

PSOs have been forced to change and adapt to the requirements of digital society that will allow them to adapt the way in which they deliver their services to citizens' needs, which include the introduction of new working methods and technological tools under the umbrella of electronic administration or e-government. These tools generate a necessity for renovation in the competences of public employees with training actions oriented both to the mastery of such tools and to the interaction that the latter permit to establish with regard to the various agents that are likely to have links with the business organization in question (citizens, firms, other public bodies, etc.). Similarly, these training actions not only need to focus on training in ICT knowledge but also on the development of other relational skills with the different agents, such as service quality or customer orientation. Furthermore, this new way of working must have a strategic orientation aimed at a continuous improvement of organizational relationships with the aforementioned agents.

Our results show that this only holds true to a certain extent for Spanish town councils: the effort dedicated to training over the decade under study increased, but
E-Government Implementation, Work Process Changes and Competency Training in Spanish Town Councils 
IJSR 5 mostly in operational terms. Although public employees had developed a positive attitude towards the introduction of new ways of working as well as towards IT upgrading, a lack of transfer of this training to work routines seemed to exist which might render the investment fruitless. Furthermore, the results appear to reveal a tendency to focus on tangible, short-term achievements instead of addressing e-government as a whole.

Town councils should therefore not only assign resources to provide their employees with skills and knowledge but also to encourage them to deploy their newly acquired competences towards a more efficient public service provision process. In fact, competency-based human resource management deals with a higher productivity of public employees not only in terms of efficacy but, most of all, in terms of efficiency. This entails a change in the formulation of e-government strategies, focusing more on the consequences and the justification for training and work transformations instead of applying a needs-by policy.

Consequently, both the public managers and the politicians involved in training processes need to reflect on the long-term effects of their decisions or - alternatively - the absence of such effects. Short-term 'patches' are only useful to meet a specific need during a certain period, whereas change management requires a more farreaching, long-term look which can overcome the budgetary limits and the traditional bureaucratic barriers.

Finally, amongst the limitations faced in the present study stands out not having considered certain parameters which might influence the strategic orientation level in the implementation of this e-government model beyond the short-term, operational limits that mean a mere accommodation to the present-day technological imperatives within the context of relationships between entities and citizens. The statistical analysis is merely descriptive, although it provides the researchers with clear results. A possible future line of research could thus focus on performing a cluster analysis that takes into account other study-universe-defining variables such as population, geographical area or the political ideology of municipal governments. This will definitely allow us to undertake a more comprehensive explanatory analysis about the causes and effects of specific strategic developments.

\section{References}

Åkesson, M., Skålén, P. and Edvardsson, B. (2008). E-Government and service Orientation: Gaps Between Theory and Practice, International Journal of Public Sector Management, Vol. 21, No. 1 , pp. 74-92.

Bueno García, O. (2002). Modernización de la AAPP, líneas estratégicas para la e-Administración. Retrieved May 25, 2005 from http://www.lawebmunicipal.com

Burn, J. and Robins, G. (2003). Moving Towards E-Government: ACase Study of the Organisational Change Process, Logistics Information Management, Vol. 16, No.1, pp.25-35.

De Luna Noyola, Á. G. (2008). Capital humano. Gestión por competencias laborales en la administración pública,Trillas, México.

De Vries, J. (2010). Is New Public Management Really Dead?, OECD Journal on Budgeting, Vol. 10, No. 1, pp. 1-5.

Del Águila Obra, A. R. (2000). Comercio Electrónico y Estrategia Empresarial: Hacia la Economía Digital, RA-MA, Madrid. 
Dunleavy, P. and Hood, C. (1994). From Old Public Administration to New Public Management, Public Money and Management, Vol. 14, Sept.-Oct., pp. 9-16.

Dunleavy, P., Margetts, H., Bastow, S. and Tinkler, J. (2006). New Public Management Is Dead: Long Live Digital-Era Governance, Journal of Public Administration Research and Theory, Vol. 16, No. 3, pp. 467-494.

FEMP: Federación Española de Municipios y Provincias (2002). Informe sobre experiencias de modernización y calidad. Retrieved November 2004 from http://www.lawebmunicipal.com

Ferlie, E., Ashburner, L., Fitzgerald, L. and Pettigrew, A. (1996). The New Public Management in Action, Oxford University Press, Oxford.

Galindo Meño, C. (2004). La nueva función pública y el cambio en la administración, paper presented at theI Seminario Nacional de Gestión Pública: Nuevos retos en el horizonte de las Administraciones Públicas, Murcia, Spain, April 2-4.

Grant, R. (1996). Towards a Knowledge-Based Theory of the Firm, Strategic Management Journal, Vol. 17, Special Winter Issue, pp. 109-122.

Guijarro, E., Babiloni, E. and Cardós, M. (2015). La Gestión por Competencias ane la Administración Pública Española. Retrieved March 2017 from https://riunet.upv.es/ bitstream/handle/10251/53293/Gesti\%C3\%B3n\%20por\%20competencias\%20en $\% 20$ las $\% 20$ Admones $\% 20 \mathrm{P} \% \mathrm{C} 3 \%$ BAblicas.pdf? sequence $=1 /$

Ho, A. T. (2002). Reinventing Local Governments and the E-Government Initiative, Public Administration Review, Vol. 62, No. 4, pp. 434-444.

Holden, S., Norris, D. and Fletcher, P. (2003). Electronic Government at the Local Level, Public Performance and Management Review, Vol. 26, No. 4, pp. 325-344.

Hood, C. (1991). A New Public Management for All Seasons?, Public Administration, Vol. 69, No. 1, pp. 1-19.

Hood, C. (1995). The "New Public Management" in the 1980s - Variations on a Theme, Accounting, Organizations and Society, Vol. 20, No. 2-3, pp. 93-110.

Johnson, R. and Mullen, T. (2000). Electronic Auctions for Delinquent Tax Properties: E-Government in Riverside County, California, Government Finance Review, Vol. 16, No. 1, (February), pp. 19-21.

Mahler, J. and Regan, P. (2003). Developing Intranets for Agency Management, Public Performance and Management Review, Vol. 26, No. 4, pp. 422-432.

Margetts, H. (2009). The Internet and Public Policy, Policy and Internet, Vol. 1, No. 1, pp. 1-21.

McIvor, R., McHugh, M. and Cadden, C. (2002). Internet Technologies: Supporting Transparency in the Public Sector, International Journal of Public Sector Management, Vol. 15, No. 3, pp. $170-87$.

Norris, D. and Reddick, C. (2012). Local E-Government in the United States: Transformation or Incremental Change?, Public Administration Review, Vol. 73, No. 1, pp. 165-175.

Op de Beeck, S., and Hondeghem A. (2010). Competency Management in the Public Sector: Three Dimensions of Integration, paper presented at the International Research Society for Public Management (IRSPM) Conference, Berne, Switzerland, April 7-9.

Prokopiadou, G., Papatheodorou, C. and Moschopoulos, D. (2004). Integrating Knowledge Management Tools for Government Information, Government Information Quarterly, Vol. 21, No. 2, pp. 170-198.

Schedler, K. and Scharf, M. C. (2001). Exploring the Interrelations Between Electronic Government and the new Public Management, [in:] B. Schmid, K. Stanoevska-Slabeva and V. Tschammer (Eds.), Towards the E-Society. E-Commerce, E-Business, and E-Government, Kluwer, Boston, MA.

Šiugždinienè, J. (2006). Competency Management in the Context of Public Management Reform, Public Policy and Administration, Vol. 1, No. 18, pp. 26-33.
E-Government Implementation, Work Process Changes and Competency Training in Spanish Town Councils 


\section{IJSR} 5
Sotiraku, T. and Zeppou, M. (2004). The "MATE" Model: A Strategic Knowledge Technique on the Chessboard of Public-Sector Modernization, Management Decision, Vol. 42, No. 1, pp. 69-88.

Spicer, M. (2015). Public Administration in a Disenchanted World: Reflections on Max Weber's Value Pluralism and His Views on Politics and Bureaucracy, Administration and Society, Vol. 47, No.1, pp. 24-43.

Torres, L., Pina, V. and Acerete, B. (2005). E-Government Developments on Delivering Public Services among EU Cities, Government Information Quarterly, Vol. 22, No. 2, pp. 217-238.

Weber, M. (1979). Economy and Society, University of California Press, Berkeley. 